\title{
The Courseware of Discontinuous Nature of Matter in Teaching the States of Matter and Their Changes
}

\author{
Wahyu Sopandi \\ Indonesia University of Education, Indonesia, wsopandi@upi.edu
}

\section{Asep Kadarohman}

Indonesia University of Education, Indonesia.kadar@upi.edu

\section{Momo Rosbiono}

Indonesia University of Education, Indonesia

\author{
Abdul Latip \\ Graduate School, Indonesia University of Education, Indonesia \\ Rendi Restiana Sukardi \\ Graduate School, Indonesia University of Education, Indonesia
}

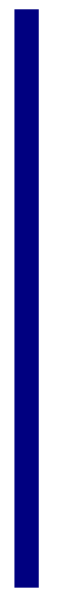

Among three levels of chemical representation, the sub-microscopic level is the most difficult to learn by students. To solve the problem, it is assumed that the concept of the discontinuous nature of matter or particle concept should be mastered initially by students before they learn sub-microscopic representations of further chemical phenomena. 131 junior high school students from two schools participated in this study. The study was carried out by implementing structureoriented chemistry teaching on the particle concept that was assisted by the courseware and was continued by teaching the changing state of matter. The research instruments were written tests, questionnaire, observation sheet and interview guideline. Research data were collected before and after the use of the courseware, as well as before and after the teaching of the changing states of matter. The results show that the use of the courseware increases students' understanding of the particle concept for both male and female groups. Meanwhile, particle concept only affects the students' understanding of sub-microscopic representations of the changing states of matter in general and based on gender.

Keywords: courseware, discontinuous nature of matter, sub-microscopic level, states of matter and their changes, gender

Citation: Sopandi, W., Kadarohman, A., Rosbiono, M., Latip, A., \& Sukardi, R. R. (2018). The Courseware of Discontinuous Nature of Matter in Teaching the States of Matter and Their Changes. International Journal of Instruction, 11(1), 61-76. https://doi.org/10.12973/iji.2018.1115a 


\section{INTRODUCTION}

In learning science, students do not only observe various natural phenomena but also learn to understand how the natural phenomena exist or occur (Meritt et al., 2007; Merino and Sanmarti, 2008). Chemistry as part of the natural science aims to help students understand various chemical phenomena. Students can study chemistry in the classroom through experiments, demonstrations or daily life experiences. After learning chemistry at macro level, they learn to explain the phenomena on the particle or submicroscopic level. Finally, students learn to communicate the phenomena scientifically with chemical terminology on the symbolic level. It means that students can develop better scientific understanding by engaging the construction of representation (Tang et al., 2014). Thus, it can be concluded that studying chemistry includes aspects of macroscopic, sub-microscopic and symbolic level (Barak and Farraj, 2013; Adadan et al., 2010; Treagust et al., 2003; Wu et al., 2001; Johnstone, 1991).

The above description shows that understanding sub-microscopic level is the key to help students to understand the phenomena and also the chemical language and symbols that represent the phenomenon being studied. It shows that sub-microscopic level can serve as a bridge between macroscopic and symbolic levels (Barke, 1988, as cited in Sopandi et al., 2009). Previous research results revealed that many students have difficulties in understanding sub-microscopic level. This happened due to lack of sub-microscopic level introduction in learning (Ozmen, 2011). The lack of sub-microscopic level understandings has led to students' difficulty in learning difficult chemistry concepts (Williamson and Abraham, 1995).

As described earlier, understanding sub-microscopic level is the key to understand a variety of chemical phenomena (Harrison and Treagust, 2002). This suggests that an understanding of the concept that any matter is composed of particles that make up matter is a prerequisite to teach the concept of sub-microscopic level. So the understanding of the particle concept is necessary to be mastered by students before they learn sub-microscopic level concepts to explain various phenomena studied in chemistry (Ozmen, 2011) because the low prior knowledge impacts to lack representation skill and conceptual understanding (Corradi et al., 2012). Engaging prior knowledge would help students to determine and convert concepts into visual representation (Tajudin and Chinnapan, 2016).

Based on the science history, the acceptance of the concept that matter is discontinuous by the scientific community took about 2000 years from the introduction of the idea by Democritus. We do not have to take a long time to help students understand the discontinuous nature of matter or particle concept. However, it seems to be unfair if we teach these concepts in just a few minutes. For example, by merely saying that matter is discontinuous and a part will give a result that cannot be again subdivided. As a result of the lack of introduction of the particle concept, many related misconceptions occur (Ozmen, 2011; Tytler et al., 2007; Novick and Nussbaum, 1978).

According to Piaget, junior high school students aged over 11 years may be in the phase of formal operational thinking. This means that they should be able to think abstractly. 
However, previous studies showed that even in senior high school many students still think concretely (Snead, 2011; Stork, 1988, as cited in Sopandi, 2004). If so, there will be a gap between the demands of abstract thinking when studying sub-microscopic level and the level of students' thinking which is still on the concrete level. This gap explains why students face difficulties in learning sub-microscopic level. Hence, to help introducing this level, a media that helps students to see and understand sub-microscopic level explanations of chemical phenomena is needed. Learning chemistry through drawing media such as animations enhances students' interest to study representation in chemistry (Barak and Farraj, 2013). In this case, the media must be able to reduce the abstraction level of sub-microscopic level by giving students both its visualization and relevant verbal explanation. Teachers should integrate visual tool as representation in teaching and allow students to represent students' understanding not only verbally but also pictorially. The pictorial forms of representations involve student-generated drawings, dynamic molecular animations, and the static particle models of the three states of matter (Adadan et al., 2010).

One of the media that can display abstract concepts is a computer-based media. Computer animation and modelling is an effective tool to teach the particle concepts of matters because it can help students to build up mental models of sub-microscopic level in their mind (Ozmen, 2011). The use of computer-based media can also facilitate students in understanding the relationship of various levels of representation and reduce misconceptions that often occur (Barnea and Dori, 1999; Mayer and Moreno, 2002). Teachers should integrate models, media, or courseware into their instruction as a means of explaining abstract concepts or unobservable phenomena (Adadan et al., 2010). Designed instruction using representation based animation can be useful in promoting and maintaining students' scientific understanding (Adadan, 2013).

In line with the above literature review, we conducted a study to test a courseware that is used to introduce the discontinuous nature of the matter concept. The courseware has previously been developed by a team headed by researchers. Tests are performed to see how the courseware can help students to understand the particle concept. Some previous research indicated that the use of computer-based media improves students' concept mastery (Harwood and McMahon, 1997; Mayer and Moreno, 2002) and submicroscopic representation skill (Stieff, 2011). In this study, the issue of how the understanding the particle concept will have positive effects on increasing students' conceptual understanding at macroscopic, sub-microscopic, and symbolic levels on the topic of "states of matter and their changes" was also tested.

Previous research results showed that students' concept mastery was influenced by gender (Halpern and LaMay, 2000; Kaufman, 2007; Scali et al., 2000; Taasoobshirazi and Carr, 2008). This is explained by differences in the spatial ability of males and females. Spatial ability of males seems better than that of females (Tracy, 1987, as cited in Barnea \& Dori, 1999). So, if males have a better spatial ability than females, males will be able to imagine at sub-microscopic level (abstract) better than females. Thus, male students have better opportunities to gain a better conceptual understanding at submicroscopic level than female students. But if female students are given enough 
practice, the distinction may diminish (Linn and Hyde, 1989, as cited in Barnea and Dori, 1999). So that teaching intervention assisted by the courseware can help female students who have lower spatial ability than that of male students to gain a better understanding on sub-microscopic level than that without the intervention. This is because such assistance can theoretically facilitate female students to get visual-spatial experiences and success (Terlecki and Newcombe, 2005; Barnea and Dori, 1999; Falvo and Suits, 2009).

Based on the description above, this article presents the role of courseware in teaching discontinuous nature of matter in order to increase students' understanding of particle concept. Understanding of this concept is believed to have an effect on students' concept mastery of states of matter and their changes. This research investigates how courseware influences particle concept understanding and increases representation skills of students. The specific research questions in this paper are:

1. Does the courseware of discontinuous nature of matter increase students' understanding of particle concept?

2. Does students' understanding of particle concept increase conceptual mastery of changing states of matter at macroscopic level based on gender?

3. Does students' understanding of particle concept increase conceptual mastery of changing states of matte at sub-microscopic level (both verbal and visual) based on gender?

4. Does students' understanding of particle concept increase conceptual mastery of changing states of matter at symbolic level based on gender?

Given these above research questions, the main research objectives are both to investigate the roles of the courseware of discontinuous nature of matter in increasing students' understanding of particle concept and how this understanding effects their understanding on changing states of matter at three chemical representations level (macroscopic, sub-microscopic, and symbolic). The role of the courseware and students' understanding on particle concept are analysed in general and based on gender.

\section{METHOD}

\section{Research Methods}

The research is quantitative with the quasi-experiment methods (Fraenkel et al., 2012). It is one group pretest and posttest design. This study involved students from two different schools. They were experimental groups. The group was given the first treatment in the form of teaching-learning process of the particle concept by using the courseware. To investigate the effect of the courseware on students' concept mastery, students were given tests about the particle concept before and after the first treatment. Many worldwide chemistry textbooks (including Bahasa Indonesia) introduce the particle structures of solid, liquid and gas when they are introducing states of matter and their changes. However, in chemistry teaching, there are still few efforts and media to help students to accept that all matter consist of particles separated from each other, by 
"particle-free space" between moving particles. In our consideration, this concept is very important to be accepted and understood by students firstly before they learn more about similarities and differences among the structures of solid, liquid, and gas. We hypothesized, it would be very difficult for students to learn particle structures of solid, liquid, and gas meaningfully without having this prerequisite concept. The lack of understanding about this prerequisite concept may explain why sub-microscopic level is difficult for students to understand.

In the second treatment, students were involved in the teaching-learning process about the changing states of matter. To investigate the effect of the students' conceptual mastery of the particle concept on changing states of matter, students were given tests about the concepts related to the changing states of matter.

\section{Research Subject}

This research study involved data collection from $7^{\text {th }}$ grade junior high school students in the city of Bandung, Indonesia. They are convenience samples. Convenience sampling is a group of individuals who (conveniently) are available for study (Fraenkel et al., 2012). Convenience sampling was chosen because researchers did not have ability to assign samples randomly. Available data from 65 students were used to answer the role of courseware in increasing students' understanding of concepts. Whereas, available data from 131 students were used to answer the research question regarding to students' understanding of 'states of matter and their changes'. The difference in both samples was a result of the fact that there was a group of students who did not follow the pre-test about understanding the particle concept.

\section{Data Collection Tools}

The instruments of this study were written tests, lesson plan, and the courseware, which visualize the particle concept. The main instruments to answer the research questions were written tests. The written tests were used to measure students' understanding of both the particle concept and the topic "states of matter and their changes". The content validity of written tests was evaluated by experts. They made sure that written test could fulfil all of intended content indicators (Arikunto, 2013). Teacher interview guides, lesson plan, and the courseware were also validated based on content by an expert. It shows how well a test measures the behaviour for which it is intended (Fraenkel et al., 2012). The teacher interview guide was used to explore teachers' opinions about the courseware. The lesson plans used in this study were prepared to develop students' macroscopic, sub-microscopic, and symbolic level. The courseware of discontinuous nature of matter was used to guide students in understanding the particle concept and the existence of "particle-free space" between particles. These were shown in the courseware through a number of experiments and their relevant animations that can facilitate students to understand the explanations.

\section{Data Analysis}

We calculated $\mathrm{N}$-gain average scores of pretest and posttest to determine the role of courseware implementation in students' mastery of particle concept (Hake, 1999). Mann 
Whitney test was done to investigate the significant differences of pretest-posttest scores. Whereas, analysis of variance (ANOVA) was used to know the relative effects of courseware implementation into three groups of students (high, middle, and low) based on their understanding of particle concept. The technique allows us to compare simultaneously several means with level of significance specified by the researcher (Minium et al., 1993). All of these tests were analysed by the software SPSS 17.0. The same analysis process also was done to investigate the effects of particle concept mastery on macroscopic, sub-microscopic (both visual and verbal), and symbolic representation based on students' gender.

\section{FINDINGS}

\section{The Role of the Courseware in Students' Understanding of Particle Concept}

The role of the courseware in increasing students' understanding of the particle concept (know that all matters are composed by particles separated by particle-free space) can be determined from the $\mathrm{N}$-gain average scores. In total, the $\mathrm{N}$-gain average scores were calculated based on the pre-test and post-test results of the students. To determine the role of the courseware according to the gender, $\mathrm{N}$-gain average scores were calculated based on Hake (1999). Table 1 shows us the result of students' understanding of particle concept.

Table 1

Test Results on Students' Understanding of the Particle Concept

\begin{tabular}{rrrrrrrr}
\hline \multicolumn{1}{c}{ Groups } & $\mathrm{N}$ & \multicolumn{2}{c}{ Average } & $\begin{array}{c}\text { N-gain } \\
\text { Average }\end{array}$ & SD & $\begin{array}{c}\text { Normality } \\
(\mathrm{p})\end{array}$ & Mann Whitney \\
\cline { 2 - 5 } & \multicolumn{2}{c}{ Pretest } & Posttest & & & & \\
\hline Male & 31 & $67.7 \%$ & $80,2 \%$, & 0.45 & 0.70 & 0.000 & 0.265 \\
\hline Female & 34 & $58.7 \%$ & $85,8 \%$ & 0.65 & 0.45 & 0.000 & \\
\hline Total & 65 & $63.3 \%$ & $83.0 \%$ & 0.54 & 0.59 & & \\
\hline
\end{tabular}

Note : $\quad N$-gain $=\left(S_{\text {post }}-S_{\text {pre }}\right) /\left(S_{\text {max }}-S_{\text {pre }}\right)$

$S_{\text {post }}$ is a score obtained by a student on postest

$S_{\text {pre }}$ is a score obtained by student on prestest

$S_{\max }$ is a maximum score that can be obained by student on test

The Role of Students' Understanding of the Particle Concept on Their Understanding of Changing States of Matter at Macroscopic Level

Particle concept is the prerequisite of students' understanding of changing states concept. Students' understanding of this concept could be measured from chemical representation. They are macroscopic, sub-microscopic, and symbolic representation. Students' understanding of macroscopic level (high, middle, and low) can be seen on Table 2. 
Table 2

Test Results on Students' Understanding of Macroscopic Level

\begin{tabular}{|c|c|c|c|c|c|c|c|}
\hline \multirow{2}{*}{ Groups } & \multirow{2}{*}{$\mathrm{N}$} & \multicolumn{2}{|c|}{ Average } & \multirow{2}{*}{$\begin{array}{c}\text { N-gain } \\
\text { Average }\end{array}$} & \multirow{2}{*}{$\mathrm{SD}$} & \multirow{2}{*}{ Homogeneity } & \multirow{2}{*}{$\begin{array}{c}\text { Anova } \\
\text { Test }\end{array}$} \\
\hline & & Pretest & Posttest & & & & \\
\hline High & 49 & $80 \%$ & $90 \%$ & 0.53 & 0.54 & \multirow{3}{*}{$\begin{array}{c}0.406 \\
\text { (homogeny) }\end{array}$} & \multirow{3}{*}{0.483} \\
\hline Middle & 31 & $80.83 \%$ & $90.83 \%$ & 0.45 & 0.74 & & \\
\hline Low & 23 & $74.66 \%$ & $85.16 \%$ & 0.32 & 0.79 & & \\
\hline
\end{tabular}

To see whether gender influenced the increase of understanding of macroscopic level, a test was carried out. The test results can be seen in the following table:

Table 3

Test Results on Students' Understanding of Macroscopic Level Based on Gender

\begin{tabular}{|c|c|c|c|c|c|c|c|}
\hline \multirow[b]{2}{*}{ Gender } & \multirow{2}{*}{$\mathrm{N}$} & \multicolumn{2}{|c|}{ Average } & \multirow{2}{*}{$\begin{array}{c}\text { N-gain } \\
\text { Average }\end{array}$} & \multirow[b]{2}{*}{ SD } & \multirow{2}{*}{$\begin{array}{l}\text { Normality } \\
(\mathrm{p})\end{array}$} & \multirow{2}{*}{$\begin{array}{c}\text { Mann } \\
\text { Whitney }\end{array}$} \\
\hline & & Pretest & Posttest & & & & \\
\hline Male & 51 & $77.33 \%$ & $89.33 \%$ & 0.49 & 0.62 & 0.000 & \multirow{2}{*}{0.652} \\
\hline Female & 52 & $80.66 \%$ & $89 \%$ & 0.39 & 0.73 & 0.000 & \\
\hline
\end{tabular}

The Role of Understanding the Particle Concept in the Increase of the Students' Conceptual Mastery of the Topic of Changing States of Matter at Sub-Microscopic Level

Students were required to answer questions related to sub-microscopic level in form of both drawing (visual aspect) and written explanations (verbal aspect). Students' understanding of visual aspect at sub-microscopic level was defined as students' abilities to visualize the sub-microscopic level related to the topic of changing states of matter in form of drawings or other illustrations. Verbal aspect is students' ability to explain the topic of changing states of matter by using words or verbally at sub-microscopic level. We identify the role of understanding the concept of matter discontinuity in the increase of the students' sub-microscopic level (both of visual and verbal), an ANOVA test was applied, with the following results:

Table 4

Test Results on Students' Understanding of Sub-Microscopic Level

\begin{tabular}{|c|c|c|c|c|c|c|c|}
\hline \multirow{2}{*}{ Groups } & \multirow{2}{*}{$\mathrm{N}$} & \multicolumn{2}{|c|}{ Average } & \multirow{2}{*}{$\begin{array}{c}\mathrm{N} \text {-gain } \\
\text { Average }\end{array}$} & \multirow{2}{*}{ SD } & \multirow{2}{*}{ Homogeneity } & \multirow{2}{*}{$\begin{array}{c}\text { Anova } \\
\text { Test }\end{array}$} \\
\hline & & Pretest & Posttest & & & & \\
\hline High & 65 & $10.9 \%$ & $40 \%$ & 0.33 & 0.19 & \multirow{3}{*}{$\begin{array}{c}0.037 \\
\text { (not } \\
\text { homogeny) }\end{array}$} & \multirow{3}{*}{0.002} \\
\hline Middle & 38 & $9.26 \%$ & $35.3 \%$ & 0.29 & 0.17 & & \\
\hline Low & 28 & $5.43 \%$ & $22.46 \%$ & 0.19 & 0.11 & & \\
\hline
\end{tabular}

Furthermore, SPSS 17.0 analysis shows that average score of $\mathrm{N}$-gain of visual aspect at sub-microscopic level is 0.66 for high achiever group, 0.64 for middle achiever group and 0.40 for low achiever group. Based on the test results obtained from ANOVA, the significance score is 0.001 . Whereas, average $\mathrm{N}$-gain of verbal aspect at submicroscopic level is 0.13 for high achiever, 0.03 for middle achiever, and 0.06 for low achiever. Based on the ANOVA test, the obtained significance score is 0.459 . 
To check whether gender influenced the increase of the understanding of the concept at sub-microscopic level, a test was conducted. The test results can be seen in the following table:

Table 5

Test Results on Students' Understanding of Sub-Microscopic Level Based on Gender

\begin{tabular}{cccccccc}
\hline \multirow{2}{*}{ Gender } & \multirow{2}{*}{$\mathrm{N}$} & \multicolumn{2}{c}{ Average } & N-gain & SD & $\begin{array}{c}\text { Normality } \\
\text { (p) }\end{array}$ & $\begin{array}{c}\text { Mann } \\
\text { Whitney }\end{array}$ \\
\cline { 3 - 5 } Male & 67 & $7.6 \%$ & $31.5 \%$ & 0.26 & 0.18 & 0.03 & \multirow{2}{*}{0.015} \\
Female & 64 & $10.9 \%$ & $38.6 \%$ & 0.32 & 0.17 & 0.04 & \\
\hline
\end{tabular}

We also analyzed sub-microscopic level in visual and verbal aspect by using SPSS 17.0. The results show that students' understanding of sub-microscopic level in visual aspect is 0.55 for male students and 0.65 for female students. The test on the average difference resulted in the average significance score of 0.144 . The average scores of $\mathrm{N}$-gain in submicroscopic level of verbal aspect are 0.04 for male students and 0.15 for female students. The significance score of the average difference is 0.848 .

The Role of Understanding Particle Concept in the Increase of Students' Conceptual Mastery at Symbolic Level in the Topic of Changing States of Matter

To identify the role of understanding particle concept in the increase of the conceptual mastery at symbolic level on each group, ANOVA test was used. The ANOVA test results are shown in the table below:

Table 6

Test Results on Students' Understanding of Symbolic Level

\begin{tabular}{|c|c|c|c|c|c|c|c|}
\hline \multirow[b]{2}{*}{ Group } & \multirow[b]{2}{*}{$\mathrm{N}$} & \multicolumn{2}{|c|}{ Average } & \multirow{2}{*}{$\begin{array}{l}\mathrm{N} \text {-gain } \\
\text { Average }\end{array}$} & \multirow[b]{2}{*}{ SD } & \multirow[b]{2}{*}{ Homogeneity } & \multirow{2}{*}{$\begin{array}{c}\text { Anova } \\
\text { Test }\end{array}$} \\
\hline & & Pretest & Posttest & & & & \\
\hline High & 65 & $0.75 \%$ & $44.33 \%$ & 0.43 & 0.29 & \multirow{3}{*}{$\begin{array}{c}0.562 \\
\text { (homogeny) }\end{array}$} & \multirow[t]{3}{*}{0.146} \\
\hline Middle & 38 & $0.25 \%$ & $52.16 \%$ & 0.52 & 0.27 & & \\
\hline Low & 28 & $0 \%$ & $39.5 \%$ & 0.38 & 0.30 & & \\
\hline
\end{tabular}

To see whether gender influenced the increase at symbolic level of understanding, a test was carried out. The test results can be seen in the following table:

Table 7

Test Results on Students' Understanding of Symbolic Level Based on Gender

\begin{tabular}{cccccccc}
\hline \multirow{2}{*}{ Gender } & \multirow{2}{*}{$\mathrm{N}$} & \multicolumn{2}{c}{ Average } & \multirow{2}{*}{$\begin{array}{c}\text { N-gain } \\
\text { Average }\end{array}$} & SD & Normality & $\begin{array}{c}\text { Mann } \\
\text { Whitney }\end{array}$ \\
\cline { 3 - 7 } Male & 67 & $0.5 \%$ & $39.58 \%$ & 0.39 & 0.29 & 0.02 & \multirow{2}{*}{0.011} \\
Female & 64 & $0.42 \%$ & $51.66 \%$ & 0.52 & 0.28 & 0.07 & \\
\hline
\end{tabular}

\section{DISCUSSION}

Table 1 shows that the $\mathrm{N}$-gain average obtained by the male group is 0.45 . This average score indicates that the courseware increased male group's understanding of the particle concept by $45 \%$. Meanwhile, the $\mathrm{N}$-gain average score obtained by the female group is 0.65. This average score indicates that the courseware increased female group's 
understanding of the particle concept by $65 \%$. The N-gain average score difference between male and female groups gave significance score of 0.265 . This score shows that there is no significant difference on the increase of the understanding of the particle concept between male and female groups. This means that the courseware gave the same effect on both gender in increasing the understanding of the concept. The total N-gain average (male and female data were combined) is 0.54. This score suggests that the effectiveness of the courseware in increasing students' understanding on the particle concept as a whole is $54 \%$. The effectiveness score is in the middle category. The increase is not maximal, which shows that there are other factors influencing the increase than the courseware.

Table 2 shows that the average $\mathrm{N}$-gain for the high achiever group is 0.53 , for middle achiever group is 0.45 and for low achiever group is 0.32 . From the ANOVA test, it was obtained that the significance score is 0.483 . The score shows that there is no significant difference in the increase of the conceptual mastery of macroscopic level between groups of high, middle and low achievers. These results indicate that to master the macroscopic level concept of changing states, such as mentioning the type of changing states of matter (evaporating, condensing, melting, freezing, sublimating and depositioning), does not require an understanding of the particle concept as a prerequisite. This is because, in order to know definitions of those terminologies such as evaporating (is a change from liquid to gas form), melting (is a change from solid to liquid form), freezing (is a change from liquid to solid form) and so on, students do not need to know the particle concept. The mastery of this concept can be learned by the students through doing observation and experiencing it directly in everyday life. Based on Table 3, from Mann Whitney test results significance score of 0.652 was obtained. was which indicates that there is no significant difference in the increase of the conceptual mastery at macroscopic level between male and female students. It means that both male and female students experienced the same increase in mastering the concepts related to the phenomenon of changing state of matter in everyday life. This is in line with the research conducted by Sopandi, et al. (2010) on the model development of multimedia assisted structure oriented chemistry teaching, which found that there is no significant improvement difference between the conceptual mastery of male and female students at macroscopic level. Another research that is in line with this study is that of Yanti (2011), which focused on the analysis of high school students' conceptual mastery of hydrolysis of salt based on gender. She found that there is no significant difference between male and female students' conceptual mastery of macroscopic level. From the results of the two tests mentioned above, it can be concluded that the increase of students' conceptual mastery of the changing states of matter at macroscopic level is not affected by either their understanding of the particle concept or gender.

Table 4 shows that the average $\mathrm{N}$-gain of the high group is 0.33 , the middle group is 0.29 , and the low group is 0.19 . To determine the level of difference among the three groups, ANOVA test was performed. From the test results, a significance score of 0.002 was obtained. It indicates that there is a significant difference in the increase of the students' conceptual mastery at sub-microscopic level among the groups. Based on the average score of the N-gain, it can be seen that the increase of the students' conceptual 
mastery at sub-microscopic level in the high achiever group is higher than the middle and low achiever group. This finding proves that students' understanding of the particle concept should be introduced previously to students before sub-microscopic level (structure, composition, and movement of particles) in the topic of changing states of matter that is learned by them.

In table 4 , it is shown that the understanding of the particle concept gave positive effect on the improvement of the level of conceptual mastery at sub-microscopic level significantly on the subject of changing states of matter. The higher the students' understanding of the particle concept is, the higher the students' understanding of submicroscopic level is. However, the conceptual mastery increase at sub-microscopic level is relatively low compared to the rate of mastery of other representation concepts. The low rate of sub-microscopic level conceptual mastery is in line with the results of several other studies (Ozmen, 2011; Tytler et al., 2007; Devetak et al., 2009; Eilks et al., 2007). Eilks et al. (2007) stated that although students are high achiever, they will face difficulties in explaining chemical phenomena at sub-microscopic level. It is also in line with the result of Sunyono et al. (2015) indicating that students with different initial capabilities do not perform any significant statistical differences on drawing submicroscopic representation phenomena. It indicates that another attempt to develop students' understanding of sub-microscopic level is needed, which is maximizing the use of the courseware combined with model/learning methods that are able to develop students' thinking skills.

As mentioned before, students' understanding on sub-microscopic level was divided into two categories (verbal and visual). Based on ANOVA test, we got significance score of 0.001 . It means that there is a significant difference in the increase of the mastery of visual aspect at sub-microscopic level among high, middle and low achiever groups. High achiever group had a higher increase than middle and low achiever groups. The occurrence of such difference suggests that the students' understanding of the theory of matter discontinuity that was presented using the courseware helps students to visualize the concept of changing state of matter. Constructing a visual concept is always followed by symbolic representation. Sunyono et al. (2015) stated that students preferred working with visuals and symbols rather than merely texts. This activity often involves one of the high order thinking skill (HOTS) aspects, it is creating (Tajudin and Chinnapan, 2016). It also helped students to understand the movement and arrangement of particles on the topic of matter states and its changes. The ANOVA test of verbal aspect of sub-microscopic level shows that there is no significant difference in terms of the increase of sub-microscopic concept between high, middle and low groups. It is due to the fact that all groups have difficulty in explaining the phenomenon of matter state changes verbally. Hence, the increase of the concept mastery is low in all groups. To improve and assist students in understanding the verbal aspect of sub-microscopic level, designing another way of learning that helps students to improve their ability to analyse and understand a passage is necessary.

In Table 5, the N-gain average of the male group is 0.26 and that of female group is 0.32 . The test on the difference of average using the Mann Whitney test showed a 
significance score of 0.015 . This indicates that there is a significant difference between male and female group in the increase of the conceptual mastery at sub-microscopic level. The female group is better than the male group. The significant difference in the increase of the conceptual mastery at sub-microscopic level between men and women was because the female students group has a better understanding of the particle concept than the male students group. Hence, the group of female students has a better preparedness in terms of understanding the particle concept when studying changing states of matter.

We also analysed visual and verbal aspect of sub-microscopic level based on the gender. The test on the average difference resulted in the average significance score of 0.144 , which shows that there is no significant difference in the increase of the mastery of the visual aspects of sub-microscopic level concepts between male and female group. Such finding indicates that the courseware can reduce the gap of visual-spatial abilities of males and females. Therefore, the courseware is one of the effective learning media in providing a visual-spatial experience for female, who have lower visual-spatial ability than male. This is in line with several studies which found that the use of computerbased instructional media can reduce the gap of visual-spatial abilities between men and women, such as Barnea and Dori (1999); Terlecki and Newcombe (2005); Falvo and Suits (2009) and Sopandi, et al., (2010). Whereas, the significance score of the average difference in verbal aspect of sub-microscopic level is 0.848 , which indicates that there is no significant difference between males and females in terms of increase in verbal aspect of sub-microscopic level. This is because both male and female students experienced the same difficulty in explaining the sub-microscopic level on the topic of "changing states of matter" verbally. That is why the N-gain scores of both groups are equally low.

From the results of the two tests mentioned above, it can be concluded that the increase of mastery of sub-microscopic level is influenced by their understanding of the particle concept and also their gender. However, the gender effect is also likely to occur as the female participants have a better understanding on the particle concept than the males, $84.6 \%$ versus $78.2 \%$ (see table 1). To test whether gender effect is really influential, male and female groups with the same particle concept understanding level need to be compared in terms of the increase of their understanding at sub-microscopic level on the topic of the changing states of matter.

Table 6 shows that the average $\mathrm{N}$-gain is at 0.43 for high achiever group, at 0.52 for middle achiever group, and 0.38 for low achiever group. From the ANOVA test results, a significance score is obtained at 0.146 . The number shows that there is no significant difference in the increase of the conceptual mastery at symbolic concept level among groups of high, middle and low achievers. It happens because to master the topic of changing states of matter at the symbolic level, students are not required to master the particle concept. Although symbolic representation often leads student to confusion (De Bock et al., 2015) but it can be easier and concrete once they are decoded (Corradi et al., 2015). Because of that, mastery of simple symbolic level, such as element symbols or phase symbol can be obtained through memorizing, which is in line with Taber's 
(2009) statement that simple chemical symbols and molecular formulas can be obtained through memorizing.

Table 7 shows that the average $\mathrm{N}$-gain of male students is $39 \%$ and the average $\mathrm{N}$-gain of female students is 0.52 . These scores indicate that the female students' increase in understanding of symbolic level is higher than that of the male students. The test result on average difference shows a significance score of 0.011 , which indicates a significant difference in the increase of the mastery of the symbolic level concepts between the female and male students. The better rate of increase among female students is also likely due to the fact that female students have a better understanding on the changing state of matter concept at sub-microscopic level, which makes it easier to understand at symbolic level (see table 5).

\section{CONCLUSION}

Based on findings, it could be summarized that the use of courseware of discontinuous nature of matter increased students' understanding of the particle concept for both male and female groups. However, there was no difference in the improvement based on gender generally. There was no effect of students' understanding of the particle concept on the increase in their understanding of macroscopic and symbolic levels about changing states of matter. Students' understanding of the particle concept has a positive influence on the improvement of the conceptual understanding of sub-microscopic level about changing states of matter. The higher the level of students' understanding of the particle concept, the higher the increase in their understanding of the concept of submicroscopic level about changing states of matter. The increase of female group's understanding is higher than that of male group. This is likely due to female group's understanding on the particle concept. According to the teachers involved in this study, the use of courseware in teaching-learning about changing states of matter motivated their students to be more diligent in their study.

The courseware is proven to be able to help students increase their conceptual understanding of the discontinuous nature of the matter. Therefore, the courseware should be used by teachers as a medium to aid students to understand the particle concept: the existence of the particles and the "particle-free space" should be taught. The findings show that the teaching of states of matter should be based on the particle model of matter: the movement of particles and the "particle-free space" between particles is a prerequisite to understand the states of matters. The findings also show that students' understanding of the particle concept influences only the visual aspect of submicroscopic level of changing states of matter, not the verbal aspect: the increase of the verbal aspect is relatively low. In line with this finding and its interpretation, it is necessary to conduct a further research on improving the quality of verbal aspects in students' understanding of sub-microscopic levels. When students have understood the particle model of matter and have applied this model for reflection the changes states of matter - they should also understand dissolving substances into water or other solvents, and also diffusion process of two gases are easy to visualize. However, this is need to be proved by further researches. 


\section{ACKNOWLEDGEMENT}

The authors wish to thank Graduate School, Indonesia University of Education for the financial support for the development of research project.

\section{REFERENCES}

Adadan, E. (2013). Using multiple representation to promote grade 11 students' scientific understanding of the particle theory of matter. Research in Science Education, 43 (3), 1079-1105.

Adadan, E., Trundle, K. C., \& Irving, K. E. (2010). Exploring grade 11 students' conceptual pathways of the particulate nature of matter in the context of multi representational instruction. Journal of Research in Science Teaching, 47 (8), 10041035.

Arikunto, S. (2013). Prosedur penelitian: Suatu pendekatan praktik. Jakarta: PT Rineka Cipta.

Barak, M. \& Farraj, R. H. (2013). Integrating model-based learning and animations for enhancing students' understanding of proteins structure and function. Research in Science Education, 43 (2), 619-636.

Barnea, N., \& Dori, J. Y. (1999). High-school chemistry students' performance and gender differences in a computerized molecular modelling learning environment. Journal of Science Education and Technology, 8 (4), 257-271.

Corradi, D., Clarebout, G., \& Elen, J. (2015). Cognitive dissonance as an instructional tool for understanding chemical representations. Journal of Science Education and Technology, 24 (5), 684-695.

Corradi, D., Elen, J., \& Clarebout, G. (2012). Understanding and enhancing the use of multiple external representations in chemistry education. Journal of Science Education and Technology, 21 (6), 780-795.

De Bock, D., Van Dooren, W., \& Verschaffel, L. (2015). Students' understanding of proportional, inverse proportional, and affine functions: Two studies on the role of external representations. International Journal of Science and Mathematics Education, $13(1), 47-69$.

Devetak, I., Vogrinc, J., \& Glazar, S.A. (2009). Assessing 16-year-old student' understanding of aqueous solution at sub-microscopic Level. Research in Science Education, 39 (2), 157-179.

Eilks, I., Moellering, J., \& Valanides, N. (2007). Seventh-grade students' understanding of chemical reactions: Reflections from an action research interview study. Eurasia Journal of Mathematics, Science \& Technology Education, 3 (4), 271-286. 
Falvo, D. A., \& Suits, J. P. (2009). Gender and spatial ability and the use of specific labels and diagrammatic arrows in a micro-level chemistry animation. Journal of Educational Computing Research, 41 (1), 83-102.

Fraenkel, J. R., Wallen, N. E., \& Hyun, H. H. (2012). How to design and evaluate research in education. New York : McGraw-Hill.

Hake, R. R. (1999). Analyzing change/gain scores. Dept. of Physics, Indiana University 24245 Hatteras Street, Woodland Hills, CA, 91367 USA, Retrieved 10 March, 2011 from http://www.physics.indiana.edu/ sdi/AnalyzingChange-Gain.pdf

Halpern, D. F., \& LaMay, M.L. (2000). The smarter sex: A critical review of sex differences in intelligence. Educational Psychology Review, 12(2), 229-246.

Harrison, A. G., \& Treagust, D. F. (2002). The particulate nature of matter: Challenges in understanding submicroscopic world, In J. K. Gilbert, O. De Jong, R. Justi, D. F. Treagust and J. H. Van Driel (Eds.), Chemical education: Towards research-based practice (pp. 189-212). Dordrecht: Kluwer Academic Publishers.

Harwood, W. S., \& McMahon, M. M. (1997). Effect of integrated video media on student achievement and attitudes in high school chemistry. Journal of Research in Science Teaching, 34 (6), 617-631.

Johnstone, A. H. (1991). Why is science difficult to learn? Things are seldom what they seem. Journal of Computer Assisted Learning, 7(2), 75-83.

Kaufman, S. B. (2007). Sex differences in mental rotation and spatial visualization ability: Can they be accounted for by differences in working memory capacity? Intelligence, 35(3), 211-223.

Mayer, E., \& Moreno. (2002). Aids to computer-based multimedia learning. Learning and Instruction, 12(1), 107-119.

Merino, C., \& Sanmarti, N. (2008). How young children model chemical change". Chemistry Education Research and Practice, 9(3), 196-207.

Meritt, J., Shwartz, Y., \& Kracjik, J. (2007, April). Middle school students' development of the particle model of matter. National Association of Research in Science Teaching, New Orleans, LA.

Minium, E. W., King, B. M., \& Bear, G. (1993). Statistical reasoning in psychology and education. John Wiley \& Sons, Inc: New York.

Novick, S., \& Nussbaum, J. (1978). Junior high school pupils' understanding of the particulate nature of matter: An interview study'. Science Education, 62(3), 273-281.

Ozmen, H. (2011). Turkish primary students' conceptions about the particulate nature of matter. International Journal of Environmental \& Science Education, 6(1), 99-121. 
Scali, R. M., Brownlow, S., \& Hicks, J. L. (2000). Gender differences in spatial task performance as a function of speed or accuracy orientation. Sex Roles, 43 (5/6), 359376.

Snead, L. P. (2011). Difficulties teaching abstract concept in secondary chemistry classroom. $\quad$ Retrieved $\quad 7 \quad$ June, 2012 from http://www.ibrarian.net/navon/paper/Loraine_P__Snead_Difficulties_Teaching_Abstrac t_C.pdf?paperid=17617863.

Sopandi, W. (2004). Raumvorstellungsvermögen und chemieverständnis im chemieunterricht. (Dissertation). University of Muenster: Schülingverlag.

Sopandi, W., Abidin, Z., \& Maulani, H. C. (2009, August). Pembelajaran Kimia yang berorientasi pada struktur: Sebuah alternatif memperkenalkan ilmu kimia pada siswa SMP untuk mengatasi masalah miskonsepsi'. National workshop on chemistry teaching at junior high school, Indonesia University of Education.

Sopandi, W., Rohman, I., Hanna, M. N., \& Kadarohman, A. (2010). Pengembangan model pembelajaran kimia yang berorientasi pada struktur berbasis multimedia untuk meningkatkan pemahaman level makroskopik, mikroskopik, dan simbolik siswa SMA. Research Report, Indonesia University of Education.

Stieff, M. (2011). Improving representational competence using molecular simulations embedded in inquiry activities. Journal of Research in Science Teaching, 48 (10), 1137 1158 .

Sunyono, Yuanita, L., \& Ibrahim, M. (2015). Supporting students in learning with multiple representation to improve student mental models on atomic structure concepts. Science Education International, 26 (2), 104-125.

Taasoobshirazi, G., \& Carr, M. (2008). Gender differences in science: An expertise perspective. Educational Psychology Review, 20 (2), 149-169.

Taber, K.S. (2009). Learning at the symbolic level. Multiple Representations in Chemical Education. Models and Modelling in Science Education, 4, 75-105.

Tajudin, M. M., \& Chinnapan, M. (2016). The link between higher order thinking skills, representation, and concepts in enhancing TIMSS task. International Journal of Instruction, 9(2), 199-214.

Tang, K. S., Delgado, C., \& Moje, E. B. (2014). An integrative framework for the analysis of multiple and multimodal representations for meaning-making in science education. Science Education, 98 (2), 305-326.

Terlecki, M. S., \& Newcombe, N. S. (2005). How important is the digital divide? The relation of computer and video game usage to gender differences in mental rotation ability. Sex Roles, 53 (5-6), 433-441. 
Treagust, D., Chittleborough, G., \& Mamiala, T. (2003). The role of submicroscopic and symbolic representations in chemical explanations. International Journal of Education, 25 (11), 1353-1368.

Tytler, R., Prain, V., \& Peterson, S. (2007). Representational issues in students learning about evaporation. Research in Science Education. 37 (3), 313-331.

Williamson, V. M., \& Abraham, M. R. (1995). The effects of computer animation on the particulate mental models of college chemistry students. Journal of Research in Science Teaching, 32 (5), 521-534.

Wu, H-K., Krajcik, J. S., \& Soloway, E. (2001). Promoting understanding of chemical representations: Students' use of a visualization tool in the classroom. Journal of Research in Science Teaching, 38 (7), 821 - 842.

Yanti, V. (2011). Analisis hasil belajar level makroskopik, mikroskopik, dan simbolik siswa SMA kelas XI pada materi pokok hidrolisis garam berdasarkan gender. (Thesis). Faculty of Mathematics and Science Education, Indonesian University of Education, Bandung. 